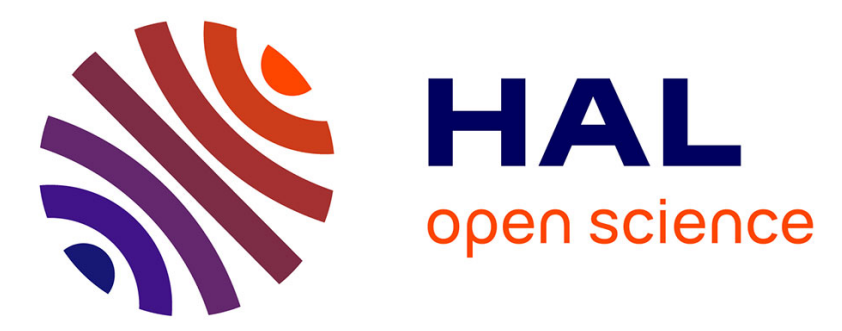

\title{
Asbestos-like actinolite crystallization during late regional variscan exhumation in the South Armorican Massif (France)
}

Geoffrey Aertgeerts, Didier Lahondère, Antoine Triantafyllou, Jean-Pierre Lorand, Christophe Monnier, Pascal Bouton

\section{To cite this version:}

Geoffrey Aertgeerts, Didier Lahondère, Antoine Triantafyllou, Jean-Pierre Lorand, Christophe Monnier, et al.. Asbestos-like actinolite crystallization during late regional variscan exhumation in the South Armorican Massif (France). EGU 2020 - Online, May 2020, Vienne - Online, Austria. 10.5194/egusphere-egu2020-8001 . hal-02469127

\section{HAL Id: hal-02469127 https://hal-brgm.archives-ouvertes.fr/hal-02469127}

Submitted on 6 Feb 2020

HAL is a multi-disciplinary open access archive for the deposit and dissemination of scientific research documents, whether they are published or not. The documents may come from teaching and research institutions in France or abroad, or from public or private research centers.
L'archive ouverte pluridisciplinaire HAL, est destinée au dépôt et à la diffusion de documents scientifiques de niveau recherche, publiés ou non, émanant des établissements d'enseignement et de recherche français ou étrangers, des laboratoires publics ou privés. 
EGU2020-8001

EGU General Assembly 2020

(c) Author(s) 2020. This work is distributed under

the Creative Commons Attribution 4.0 License.

\title{
Asbestos-like actinolite crystallization during late regional variscan exhumation in the South Armorican Massif (France)
}

\author{
Geoffrey Aertgeerts ${ }^{1}$, Didier Lahondère ${ }^{2}$, Antoine Triantafyllou ${ }^{3,4}$, Jean-Pierre Lorand ${ }^{5}$, Christophe \\ Monnier ${ }^{5}$, and Pascal Bouton ${ }^{6}$ \\ 1BRGM, DAT/OMR/GUY/CAY, Cayenne, French Guiana (g.aertgeerts@brgm.fr) \\ ${ }^{2}$ BRGM, DGR/GSO, Orléans, France \\ ${ }^{3}$ University of Liege, Department of Geology, Sart Tilman, Belgium \\ ${ }^{4}$ University of Arizona, Department of Geosciences,Tucson, Arizona, USA \\ ${ }^{5}$ University of Nantes, LPGN-CNRS-UMR-6112, Nantes, France \\ ${ }^{6}$ Oolite, Monnière, France
}

In this study, two types of natural asbestos-like actinolite occurrences were sampled in order to understand their tectonic and metamorphic signification. Studied rocks were collected within two Variscan ophiolitic formations (Tréogat and Pont de Barel Formations, South Armorican Massif, Western France), mainly composed of amphibolites, and which recorded amphibolite to greenschist facies metamorphism. In these localities, the natural asbestos-like actinolite occurrences are closely related with the development of tectonic structures such as extension veins, tension gashes, $\sigma$ and $\delta$-type boudins. Field and petrostructural studies together with optical microscope, SEM and electron-microprobe analyses (EPMA) allowed to link early steps of the retrograde deformation event, during which acicular hornblende crystallizes in extension veins showing fuzzy boundaries or in hosting rock, with the late step of the same deformation event, during which hornblende is downgraded into asbestos-like actinolite synchronous with felsic melt circulation and tectonic structures opening. Field and microtectonic observations point to a sinistral strike-slip shearing for Pont de Barel formation and to a sinistral transtensive shearing for the Tréogat formation, which is consistent with the late regional variscan exhumation of the South Armorican Terrane. SEM observations show that asbestos-like actinolite originate from hornblende crystallographic plan fragmentation, starting first along the (110) plans and continue both along the (100) and (110) plans. EPMA analyses show that Na-Al-Si metasomatism is associated with this fragmentation. Temperature estimates of chlorite crystallization after hornblende are around $300^{\circ} \mathrm{C}$ for the Tréogat Formation and $200^{\circ} \mathrm{C}$ for the Pont de Barel Formation, suggesting that amphibole fragmentation can occur over a wide temperature range. Additionally, Principal Component Analysis was performed using crystallographic sites distribution. Results show a clear correlation between actinolite $\mathrm{Si}(\mathrm{T})$ and hornblende $\mathrm{Al}(\mathrm{T}), \mathrm{Al}(\mathrm{C})$ and $\mathrm{Na}(\mathrm{A})$ crystallographic sites, suggesting that asbestos-like actinolite after hornblende fragmentation is rather due to a decrease of pressure within the tectonic structures, as Al in amphibole is pressuredependent. This decrease could be due to the fluid pressure, which is supra-lithostatic during tectonic structures opening. 
